Tayebeh Ghorbani ${ }^{1}$, Kianoosh Cheghamirza ${ }^{1}$, Kosar Bardideh $^{1}$, Parastoo Basiri Shoar ${ }^{1}$

${ }^{1}$ Agronomy and Plant Breeding Department, Razi University, Kermanshah, Iran; No.15- lintang Ilmu 4- Taman Ilmu- Nibong Tebal 14300- Penang Island- Malaysia e-mail: Ghorbani_tayebeh@yahoo.com

\title{
RECOGNITION AND DETERMINATION OF RELATED TRAITS IMPORTANCE WITH SEED YIELD IN CHICKPEA (CICER AIETINUM)
}

\begin{abstract}
To study the relationship between seed yield and its components 5 varieties and 18 different genotypes of Cicer arietinum were evaluated. This study was carried out under dryland farming during 2007 in research farm of Razi university. Path analysis showed that in the first level of yield, the highest direct effect was related to biological yield and the highest indirect effect was related to seed number per plant due to biological yield. In second level of yield due to the seed number per plant double seed pod number had the highest direct effect and the highest indirect effect was related to hundreds seed weight due to double the seed pod number. In second level of yield due to biological yield, the highest direct effect was related to high plant and the highest indirect effect was related to high plant due to second branch number. In the third level of yield due to a hundred seed weight, the highest direct effect was related to pod diameter and the highest indirect effect was related to pod length due to pod diameter. Factor analysis showed that 5 factors explained 81.65 percent of the variance. Cluster analysis based on ward method were arranged genotypes in 3 clusters.
\end{abstract}

Key words: chickpea, factor analysis and cluster analysis., path analysis, yield, yield components,

\section{INTRODUCTION}

Chickpea (Cicer arietinum) with $2 \mathrm{n}=16$ chromosome is one of the grains spices that it contains 17- 24 percent protein. According to population increasing, protein request and farm extending limitation, it is necessary to do research for improving yield and related traits with yield (Pirdadeh, 2005; Hamzeh, 2004).

Communicated by Andrzej Aniol 
The study of seed yield and effective traits on yield in chickpea genotypes showed some genetic variation for yield components. The effect of secondary branch number, hundred seed weight and pant length to yield in chickpea was positive and significant (Kanouni, 2003). The study of planting date effect on yield and yield components of chickpea in Khorasan showed a significant correlation between branch number per plant and seed yield (Porsa et al., 2003). Optimization of chickpea production management using computer simulation showed a positive significant correlation between seed yield and biological yield (Soltani et al., 2007). The study of genetic variation potential in Iranian chickpea using factor analysis defined six independent factors that they explained 62.5 percent of population variance (Aghaei et al., 2005). In a research, effective traits on seed yield in 36 chickpea lines was determined and four factors explained 77.2 percent of variance (Kamel et al., 2008). The study of chickpea genotypes variation in Turkey using factor analysis showed that one factor had a fixed level (0.99) for all of the genotypes (Vural et al., 2007). In determining the most effective traits on chickpea yield using factor analysis, a research was done and showed that the first factor contained yield and seed yield, blight resistance and plant length. Also two other factors contained branch number, pod number per plant and seed weight (Toker et al., 2004). In Pakistan, factor analysis of chickpea genotypes reported a high relationship between blight resistance and first factor (Iqbal et al., 2004). The study of chickpea genetic variation using factor analysis showed that the morphological and physiological function was increased due to hybridization between genotypes (Khan et al., 1991). The study of chickpea intraspecific variation using factor analysis reported the most significant results and explanations (Narayan et al., 1976). In a research, three factors were determined for different morphological and agronomic traits in chickpea genotypes that they explained the most of the variance (Moreno et al., 1978).

The present research was done to determine the important agronomic traits of chickpea and their relationship with yield, and recognizing some traits that they could be used for direct selection in breeding. Also in this research, the studied traits were analyzed using factor analysis, and hidden factors were recognized for studying the interrelationship between morphological traits and evaluation of chickpea local mass family relationships with together and also with famous varieties.

\section{MATERIAL AND METHOD}

In this research, 18 local masses and 5 varieties of chickpea planted on two randomized complete block design ( Table 1). There were 3 lines in per plot. Line's distances were $50 \mathrm{~cm}$, plot's distances were $100 \mathrm{~cm}$ and block's distances were $2 \mathrm{~m}$. During the research weeds were eliminated in two steps 
by hand. Sampling was done during the growing period. Final harvesting was done by hand. 18 traits were studied ( Table 2).

Table 1

List of studiem genotypes.

\begin{tabular}{ccclcccl}
\hline Row & $\begin{array}{c}\text { Name in this } \\
\text { research }\end{array}$ & $\begin{array}{c}\text { Gene bank } \\
\text { code }\end{array}$ & $\begin{array}{c}\text { Location of } \\
\text { collection }\end{array}$ & Row & $\begin{array}{c}\text { Name in this } \\
\text { research }\end{array}$ & $\begin{array}{c}\text { Gene bank } \\
\text { code }\end{array}$ & $\begin{array}{c}\text { Location of } \\
\text { collection }\end{array}$ \\
\hline 1 & 1 & 215002 & Markazi & 13 & 57 & 215813 & Unknown \\
2 & 2 & 215004 & Markazi & 14 & 79 & 216118 & Unknown \\
3 & 7 & 215056 & Unknown & 15 & 82 & 216147 & Unknown \\
4 & 8 & 215079 & Mazandaran & 16 & 83 & 216149 & Unknown \\
5 & 9 & 215161 & Unknown & 17 & 96 & 216277 & Unknown \\
6 & 18 & 215295 & Unknown & 18 & 104 & 216356 & Unknown \\
7 & 33 & 215538 & Khorasan & 19 & ILC482 & - & Turkey \\
8 & 39 & 215567 & Unknown & 20 & Bivanij & - & Kermanshah \\
9 & 41 & 215611 & Unknown & 21 & Jam & - & Fars \\
10 & 51 & 215701 & Unknown & 22 & Arman & - & ICARDA \\
11 & 52 & 215743 & Unknown & 23 & Hashem & - & ICARDA \\
12 & 54 & 215754 & Unknown & & & & \\
\hline
\end{tabular}

Table 2

List of traits measured in chickpea

\begin{tabular}{clll}
\hline Row & \multicolumn{1}{c}{ Trait } & Row & \multicolumn{1}{c}{ Trait } \\
\hline 1 & Biological Yield & 10 & Hundred Seed Weight \\
2 & Chlorophyll Amount & 11 & Fertilization Percent \\
3 & Pod Number Per Plant & 12 & Harvest Index \\
4 & Pod Length & 13 & Seed Yield \\
5 & Pod Diameter & 14 & Secondary Branch Number \\
6 & Seed Number Per Pod & 15 & Plant Length \\
7 & Single Seed Pod Number & 16 & First Flowering Date \\
8 & Double Seed Pod Number & 17 & \%50 of Flowering Date \\
9 & Seed Number Per Plant & 18 & First Poding Date \\
\hline
\end{tabular}

We used EXCEL and SPSS software for statistical analysis. 


\section{RESULT}

Because of seed yield importance, in table 3, we just showed the correlation between seed yield and other traits. The results showed that seed yield had a significant correlation with seed number per plant, biological yield, pod number per plant and single seed pod number (Table 3 ). In the study of seed yield and its related traits in chickpea genotypes, secondary branch number, hundred seed weight and plant length had a significant positive effect on seed yield (Kanouni, 2003). In the study of the chickpea planting date on yield and its components in Khorasan, there was a significant correlation between branch number per plant and seed yield (Porsa et al., 2003).

Correlation coefficients of measured grain yield traits in chickpea

\begin{tabular}{llll}
\multicolumn{1}{c}{ Traits } & $\begin{array}{c}\text { Correlation with } \\
\text { seed yield }\end{array}$ & \multicolumn{1}{c}{ Traits } & \multicolumn{1}{c}{$\begin{array}{c}\text { Correlation with } \\
\text { seed yield }\end{array}$} \\
\hline Seed yield & 1 & Hundred seed weight & 0.225 \\
Biological yield & $0.724^{* *}$ & Fertilization percent & -0.096 \\
Pod number per plant & $0.509^{*}$ & Harvest index & 0.311 \\
Pod length & 0.205 & Plant length & -0.022 \\
Pod diameter & 0.136 & Secondary branch number & 0.331 \\
Seed number per pod & 0.215 & Chlorophyll amount & 0.114 \\
Single seed pod number & $0.723^{* *}$ & First flowering date & -0.070 \\
Double seed pod number & 0.013 & \%50 flowering date & 0.183 \\
Seed number per plant & $0.494^{*}$ & First podding date & 0.161 \\
\hline
\end{tabular}

$*$ and $* *$ _ significant at $5 \%$ and $1 \%$ respectively

Fig. 1. Shows Path analysis diagram based on correlation analysis results and the true relationship between different traits. 


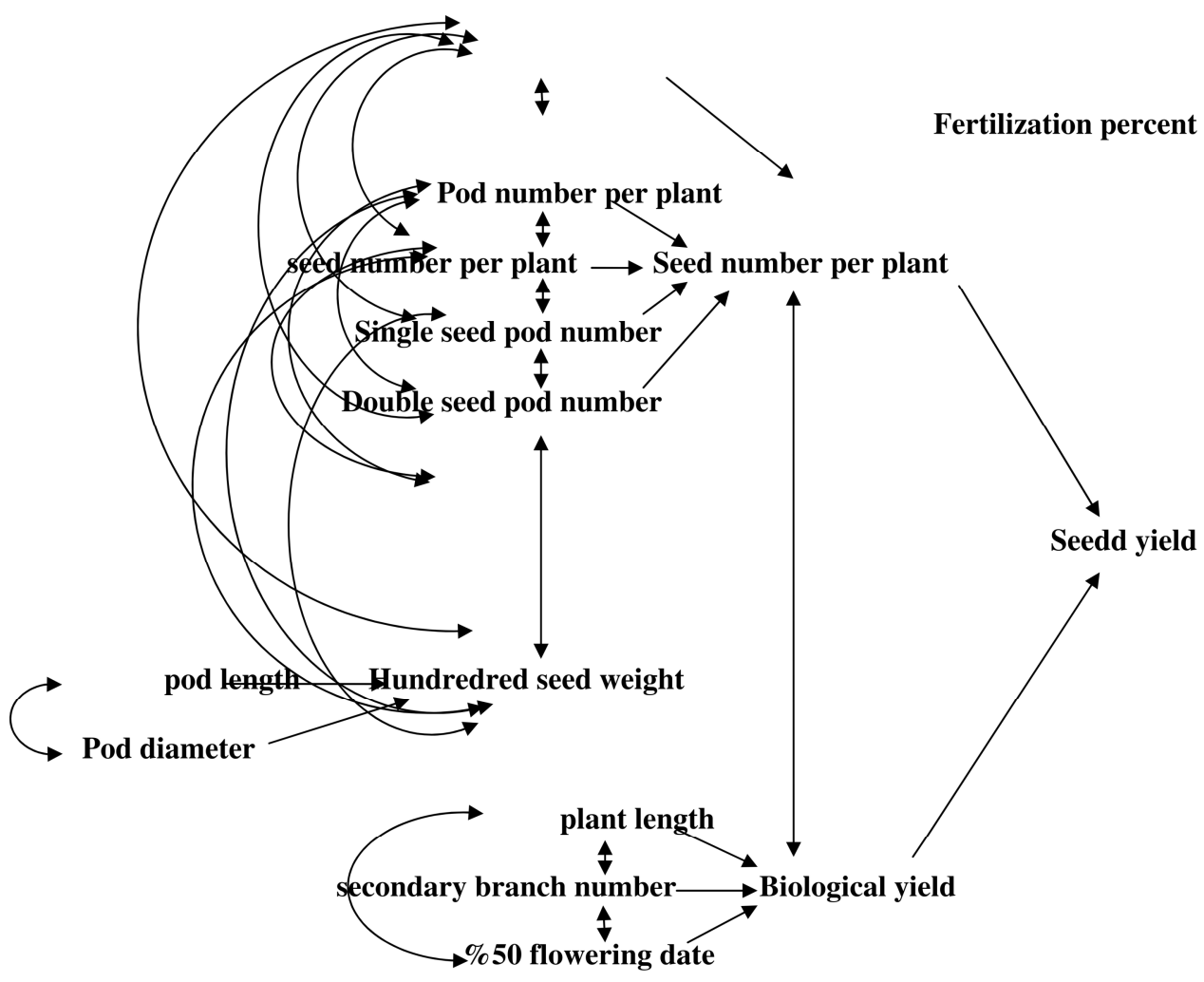

Fig. 1 Path analysis diagram for grain yield in chickpea

Path analysis results in the first level of yield

\begin{tabular}{|c|c|c|c|c|}
\hline \multirow{2}{*}{$\begin{array}{l}\text { Traits in the first } \\
\text { level of yield }\end{array}$} & \multirow{2}{*}{$\begin{array}{c}\text { Correlation with } \\
\text { seed yield per } \\
\text { plant }\end{array}$} & \multirow{2}{*}{$\begin{array}{l}\text { Frist trait direct } \\
\text { effect on seed } \\
\text { numberper plant }\end{array}$} & \multicolumn{2}{|c|}{$\begin{array}{c}\text { First trait indirect effect } \\
\text { on seed yield due to }\end{array}$} \\
\hline & & & $\begin{array}{c}\text { Seed number } \\
\text { per plant }\end{array}$ & Biological yield \\
\hline Seed number per plant & $0.494^{*}$ & 0.262 & - & 0.249 \\
\hline Biological yield & $0.724^{* *}$ & 0.628 & 0.104 & - \\
\hline
\end{tabular}

$*$ and $* *$ _ significant at $5 \%$ and $1 \%$ respectively

Path analysis results showed that highest direct effect on the first level of yield was related to biological yield and the highest indirect effect was related to seed number per plant due to biological yield ( Table 4). In the second level of yield due to the seed number per plant, the highest direct effect was related to double seed pod number and the highest indirect effect was related to a hundred seed weight due to double the seed pod number (Table 5). In second level of yield due to biological yield, the highest direct 
effect was related to plant length and the highest indirect effect was related to plant length due to the secondary branch number ( Table 6). In the third level of yield due to a hundred seed weight, the highest direct effect was related to pod diameter and the highest indirect effect was related to pod length due to the pod diameter ( Table 7).

Table 5

Path analysis results in the second level of yield due to seed number per plant.

\begin{tabular}{rcccccccc}
\hline \multirow{2}{*}{$\mathrm{A}$} & \multirow{2}{*}{$\mathrm{B}$} & $\mathrm{C}$ & \multicolumn{6}{c}{ Secondary traits indirect effect on seed number per plant due to } \\
\cline { 5 - 8 } & & & $\mathrm{I}$ & $\mathrm{II}$ & $\mathrm{III}$ & $\mathrm{IV}$ & $\mathrm{V}$ & $\mathrm{VI}$ \\
\hline I & $0.246^{\text {ns }}$ & 0.001 & - & 0.015 & -0.002 & 0.179 & -0.036 & -0.004 \\
II & $0.777^{* *}$ & -0.145 & 0.0001 & - & 0.001 & -0.144 & 0.525 & -0.007 \\
II & $0.380^{\text {ns }}$ & -0.010 & 0.0002 & -0.103 & - & -0.015 & 0.055 & -0.005 \\
IV & $0.677^{* *}$ & 0.741 & 0.0002 & -0.073 & -0.001 & - & 0.039 & -0.015 \\
V & $0.753^{* *}$ & 0.804 & 0.0001 & -0.058 & -0.004 & -0.010 & - & -0.014 \\
VI & $-0.653^{* *}$ & 0.018 & -0.0002 & 0.057 & 0.003 & 0.032 & -0.635 & - \\
\hline
\end{tabular}

**: Significant at $1 \%$, NS: non significant $\left(\mathrm{R}^{2}=0.972\right)$.

Legend:

I - Fertilization percent

II - Pod number per plant

III - Seed number per pod

IV — Single seed pod number

$\mathrm{V}$ - Double seed pod number

VI - Hundred seed weight

A - Traits of second level of yield due to seed number per plant

B - Correlation with seed number per plant

$\mathrm{C}$ - Secondary traits direct effect on seed number per plant

Path analysis results in the second level of yield due to biological yield

Table 6

\begin{tabular}{lccccc}
\hline \multirow{2}{*}{$\begin{array}{c}\text { Traits of second level of } \\
\text { yield due to biological yield }\end{array}$} & $\begin{array}{c}\text { Correlation with } \\
\text { biological yield }\end{array}$ & $\begin{array}{c}\text { Secondary traits } \\
\text { direct effect on } \\
\text { biological yield }\end{array}$ & $\begin{array}{c}\text { Plant } \\
\text { length }\end{array}$ & $\begin{array}{r}\text { Secondary } \\
\text { branch number }\end{array}$ & $\begin{array}{c}\% 50 \text { flower- } \\
\text { ing date }\end{array}$ \\
\hline Plant length & $-0.343^{\text {ns }}$ & 0.100 & - & -0.444 & 0.001 \\
Secondary branch number & $0.670^{* *}$ & 0.691 & -0.064 & - & 0.043 \\
$\% 50$ flowering date & $0.349^{\text {ns }}$ & 0.150 & 0.001 & 0.198 & - \\
\hline
\end{tabular}

$*$ and $* *$ : Significant at $5 \%$ and $1 \%$, respectively, NS: non significant $\left(\mathrm{R}^{2}=0.481\right)$ 
Recognition of determination of related traits importance with seed in chickpea ... 21

Table 7

Path analysis results in the third level of yield due to hundred seed weight

\begin{tabular}{ccccc}
\hline \multirow{2}{*}{$\begin{array}{c}\text { Traits of second level } \\
\text { of yield due to hundred } \\
\text { seed weight }\end{array}$} & $\begin{array}{c}\text { Correlation with } \\
\text { hundred seed } \\
\text { weight }\end{array}$ & $\begin{array}{c}\text { Secondary traits direct } \\
\text { effect on hundred } \\
\text { seed weight }\end{array}$ & \multicolumn{2}{c}{$\begin{array}{c}\text { Secondary traits indirect } \\
\text { effect on }\end{array}$} \\
\cline { 4 - 5 } & $0.532^{* *}$ & 0.360 & Pod length & Pod diameter \\
\hline Pod length & $0.920^{* *}$ & 0.900 & 0.198 & 0.496 \\
Pod diameter & &
\end{tabular}

**: Significant at $1 \%(0.847)$

The result of Factor analysis showed that the five factors explained 81.65 percent of variance ( Table 8 ).

Factor analysis results

Table 8

\begin{tabular}{lccccc}
\hline \multicolumn{1}{c}{ Traits } & First Factor & Second F. & Third F. & Fourth F. & Fifth F. \\
\hline 100 seed weight & $\underline{0.960}$ & 0.052 & 0.045 & -0.023 & -0.041 \\
Pod diameter & $\underline{0.932}$ & -0.052 & 0.181 & 0.008 & -0.045 \\
Double seed pod N. & $\underline{-0.847}$ & 0.101 & 0.210 & 0.087 & -0.039 \\
Seed N. Per plant & $\underline{-0.721}$ & 0.634 & 0.035 & 0.173 & 0.097 \\
Seed yield & 0.181 & $\underline{0.892}$ & 0.015 & 0.322 & -0.058 \\
Single seed N. & -0.166 & $\underline{0.887}$ & -0.119 & 0.074 & 0.139 \\
Biological yield & 0.136 & $\underline{0.803}$ & 0.357 & -0.284 & -0.080 \\
Pod N. Per plant & -0.484 & $\underline{0.759}$ & 0.214 & -0.248 & -0.074 \\
First flowering date & 0.045 & -0.049 & $\underline{0.751}$ & -0.237 & -0.206 \\
\%50 flowering date & -0.089 & 0.136 & $\underline{0.738}$ & 0.152 & 0.056 \\
First podding date & -0.126 & 0.052 & $\underline{0.669}$ & 0.600 & 0.013 \\
Pod length & 0.507 & 0.197 & $\underline{0.667}$ & -0.133 & 0.000 \\
Secondary branch N. & 0.009 & 0.523 & $\underline{0.569}$ & -0.368 & -0.295 \\
Chlorophyll amount & 0.401 & 0.143 & -0.451 & -0.010 & 0.430 \\
Harvest index & 0.087 & 0.045 & -0.222 & $\underline{0.867}$ & -0.193 \\
Seed N. Per pod & -0.278 & -0.003 & 0.136 & $\underline{0.858}$ & 0.232 \\
Fertilization percent & -0.212 & 0.080 & -0.032 & -0.125 & $\underline{0.875}$ \\
Plant length & 0.232 & -0.276 & -0.147 & 0.410 & $\underline{0.632}$ \\
\hline Variance \% & 22.034 & 20.355 & 16.044 & 14.196 & 9.023 \\
Cumulative variance \% & 22.034 & 42.39 & 58.433 & 72.629 & 81.652 \\
Stagnant root & 3.966 & 3.664 & 2.888 & 2.555 & 1.624 \\
\hline
\end{tabular}

Factor analysis is used to decrease data, recognizing of main yield components, clustering of traits, according to their relationships, and genetic variation studies. 
In this research, factor analysis was done due to principal component analysis with varimax rotation. The highest factor indexes in per factor was used to name factors. For main indexes recognizing in per factor, we just used indexes that they were more than 0.5 (Table 8).

According to factor analysis, five factors were resulted that they explained more than 81 percent of total variance. The highest indexes in first factor were related to a hundred seed weight, pod diameter, double seed pod number and seed number per plant, so it could be named seed size determination factor. The second factor was contained seed yield, single seed pod number, biological yield and pod number per plant that it explained 20.36 percent of the variance, so it could be named yield factor. The third factor explained 16 percent of the variance. The most important traits in this factor determination were first flowering date, $50 \%$ flowering date, first pod date, pod length and secondary branch number, so it could be named phonological factor. The fourth factor explained 14.20 percent of the variance. In this factor, harvest index and seed number per pod were important that it could be named harvest index factor. The fifth factor explained 9 percent of the variance. The most important traits in this factor were fertilization percent and plant length, so it could be named fertilization factor.

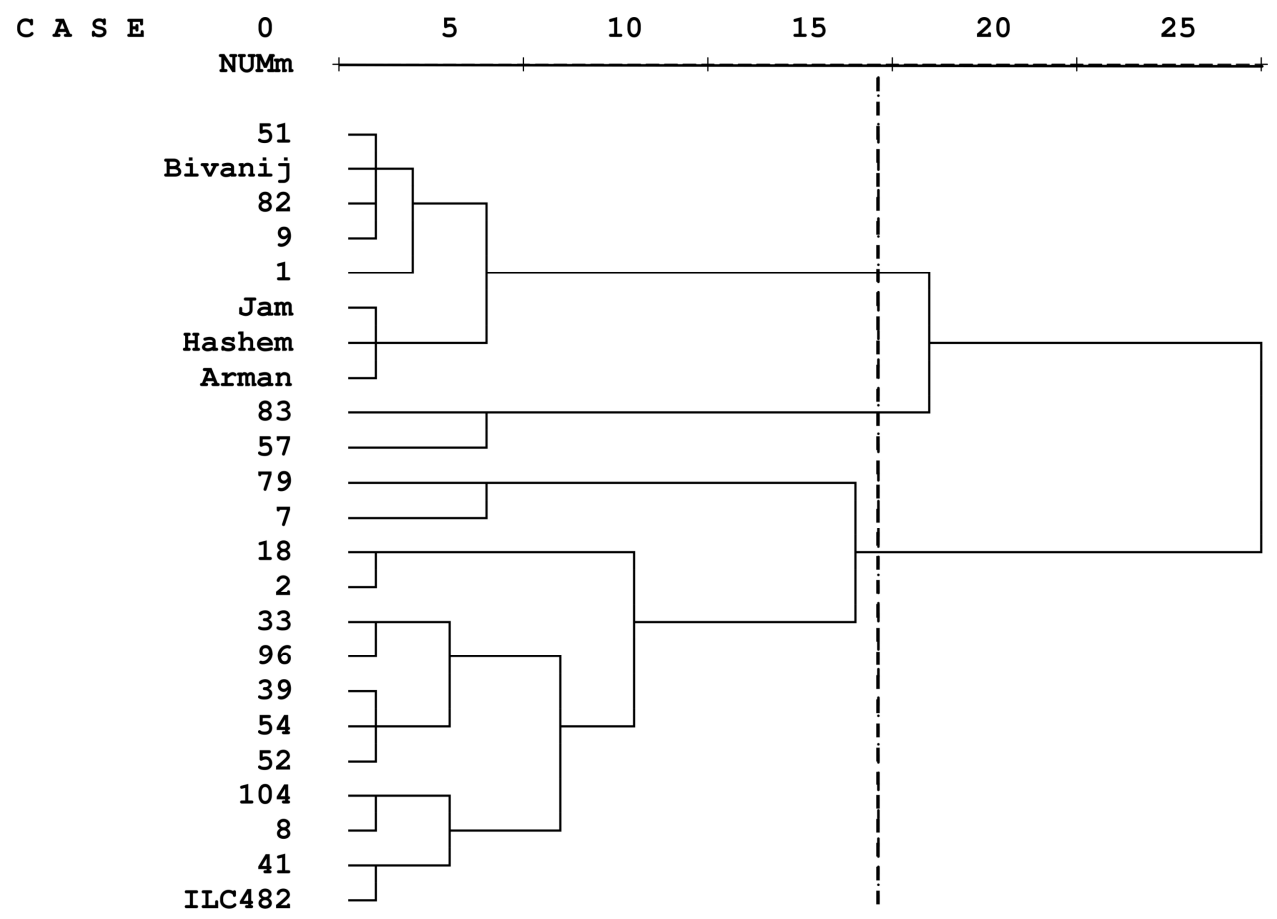

Fig. 2. Dendrogram based on the ward method of cluster analysis for studying the traits in chickpea 


\section{Cluster analysis}

To genotypes clustering based on their characters and finding out their similarity and differences, we used cluster analysis, so similar samples were arranged in one cluster.

The results of the data cluster analysis using WARD method arranged genotypes in three clusters ( Fig. 2) and result of discriminate analysis confirmed that ( Table 9).

Table 9

Discriminate analysis results based on the studied traits for clustering genotypes in chickpea.

\begin{tabular}{ccccccccc}
\hline \multirow{2}{*}{$\begin{array}{c}\text { Predicted clu- } \\
\text { sters }\end{array}$} & \multicolumn{2}{c}{ First cluster } & \multicolumn{2}{c}{ Second cluster } & \multicolumn{2}{c}{ Third cluster } & \multicolumn{2}{c}{ Total } \\
\cline { 2 - 8 } & Number & Percent & Number & Percent & Number & Percent & Number & Percent \\
\hline 1 & 8 & 100 & 0 & 0 & 0 & 0 & 8 & 100 \\
2 & 0 & 0 & 2 & 100 & 0 & 0 & 2 & 100 \\
3 & 0 & 0 & 0 & 0 & 13 & 100 & 13 & 100 \\
\hline
\end{tabular}

The first cluster contained 1, 9, 51 and 82 genotypes and Bivanij, Jam, Arman and Hashem varieties. These samples were similar together based on seed yield and biological yield with a low amount and pod length and pod diameter with high amount. The second cluster contained 57 and 83 genotypes that they were similarly based on seed yield, pod length and pod diameter with a high amount and pod number per plant with a low amount. The third cluster contained 2, 7, 8, 18, 33, 39, 41, 52, 54, 79, 96 and 104 genotypes and ILC482 variety that they were similarly based on fertilization percent first podding date with a high amount.

The result of cluster analysis based on morphological and agronomic traits was not confirmed geographical clustering. It may be for the reason that seed movement between different regions or having a common ancestor in crosses.

\section{DISCUSSION}

According to high direct effect of seed number per plant and biological yield on seed yield and a high effect of single and double seed pod number of seed number per plant, it can be resulted that selecting these traits will cause the seed number per plant increasing and finally seed yield will be increased. Also hundred seed weight had a high direct effect on seed number per plant due to double seed pod number that it is effective due to pod length and pod diameter. 
Finally because of chickpea seed size importance, we can product bigger seeds of chickpea and increase chickpea yield due to the increasing pod diameter.

\section{REFERENCES}

Aghaei, M., Mirakhorli, Vaezi, A. Sh. Khuhpaigani, A. 2005. Potential of genetic diversity in Iranian Chickpea collection. Of the first Pulses congress, 2005. Ferdosi university of Mashhad.

Hamzeh, Sh. 2004. Optimizing regeneration of chickpea and investigation of the possibilities of reporter gene (GUS) transformation of chickpea. Msc thesis, Razi university of Kermanshah.

Iqbal, S. M., Ghafoor, A. Ayub, N. Ahmad, Z. 2004. Pathogenic diversity in ascochytarabiei isolates collected from Pakistan. Pak. J. Bot., 36(2): 429-437.

Kamel M., Moradi, P. 2008. Determination of traits effective on seed yield of 36 lines of Chickpea in Northwest provinces of Iran in Dryland conditions. Seed and plant improvement journal 24: 347-357.

Kanouni H. 2003. Study of seed yield and some associated characteristics in chickpea under drought stress conditions of Kurdistan. Iranian journal of crop science. 5(2): 148-154.

Khan, I. A., Imtiaz, S., Malik, B. A. 1991. Selection of diverse parents of chickpea (Cicerarietinum L.) by multivariate analysis and degree of heterosis of their F1 hybrids.

Moreno, M. T. Cubero, J. I. 1978. Variation in CicerarietinumL. Euphytica, 27( 2): 465-485.

Narayan, R. K. J. Macefield, A. J. 1976. Adaptive responses and genetic divergence in a world germplasm collection of chick pea (Cicerarietinum L.). Theoretical and applied genetics, 47 (4): 179-187.

Pirdadeh biranvand H. 2005. Diallel analysis in Chickpea lines. Msc thesis, Razi university of Kermanshah.

Porsa, H., Nezami, A. Bagheri, A. Mohammadabadi, A. A. Rastegar, J. 2003. Effects of a fall and winter planting dates on morphological characteristics, yield and yield components of Chickpea under irrigated condition of Khorasan (Nishabur). Journal of agricultural sciences and natural resources (38). ISSN 1028-3099.

Soltani, A., Rasam, Gh. 2007. Optimizing management Chickpea production in dry farming conditions using computer simulations. The second national conference on agricultural land knowledge about Iran.

Toker, G. Cagirgan, M. I. 2004. The use of phenotypic correlations and factor analysis in determining the characters for grain yield selection in chickpea (Cicerarietinum L.). Hereditas. 140: 226-228.

Vural, H. Karasu, A. 2007. Variability studies in chickpea (Cicerarietunum L.) varieties grown in Isparta, Turkey. Revista UDO Agrícola, 7 (1): 35-40. 